\title{
PENGARUH BAURAN PEMASARAN JASA TERHADAP KEPUTUSAN NASABAH DALAM MEMILIH CU CINTA KASIH TIGAPANAH
}

\author{
Refi Mariska1, Darna Sitanggang² \\ 1,2Universitas Katolik Santo Thomas Medan Jl. Setia Budi No. 479F, 20132, Indonesia \\ Email : darna.sitanggang@gmail.com
}

\begin{abstract}
This study aims to determine and explain the effect of the service marketing mix on customer decisions to choose CU Cinta Kasih Tigapanah. The analysis method used is multiple linear regression. The population in this study were customers of CU Cinta Kasih Tigapanah during 2015-2018, totaling 10,500 people. The sampling method uses the desired maximum error. So the number of customers who were sampled was 96 people. Data collection techniques using questionnaires, interviews and documentation study. From the research results, the multiple linear regression equation is obtained as follows: $Y=1,848+0.304 X 1+0.091 X 2+0.018 X 3+0.034 X 4+0.354 X 5+0.440 X 6+0.237 X 7+$ e.This means that the process variable (X5) has the greatest influence on customer decisions, where the largest regression coefficient is 0.354 . Based on the t test, the product has a positive but not significant effect on customer decisions where the significance value is $0.061>0.05$. Price, location, promotionand physical evidence has a positive but not significant effect on customer decisions. People and process has a positive and significant effect on customer decisions. The results of the F test show that the product, price, location, promotion, people, process, physical evidence have a positive and significant effect on the customer's decision to choose CU Cinta Kasih Tigapanah. The value ( $R$ square) is 0.85 , meaning that the variations in the customer's decision to choose CU Cinta Kasih Tigapanah can be explained by the product, price, location, promotion, people, process, and physical evidence of $85.4 \%$, and the remaining $14.6 \%$ can explained by other variables not included in this study such as service quality and marketing strategy.
\end{abstract}

Keywords: Service Marketing Mix, Purchasing Decision

\section{PENDAHULUAN}

Setiap perusahaan mempunyai tujuan untuk dapat tetap hidup dan berkembang, tujuan tersebut hanya dapat dicapai melalui usăha mempertahankan dan meningkatkan tingkat keuntungan/laba perusahaan. Usaha ini hanya dapat dilakukan apabila perusahaan dapat mempertahankan dan meningkatkan penjualannya, melalui usaha mencari dan membina langganan, serta usaha menguasai pasar. Tujuan ini hanya dapat dicapai apabila perusahaan melakukan strategi yang mantap untuk dapat menggunakan kesempatan atau peluang yang ada dalam pemasaran, sehingga posisi atau kedudukan perusahaan di pasar dapat di pertahankan dan sekaligus ditingkat kan.

Jasa merupakan kegiatan yang dapat diidentifikasikan secara tersendiri, yang pada hakekatnya bersifat tak teraba (intangible), yang merupakan pemenuhan kebutuhan dan tidak harus terikat pada penjualan produk.Salah satu perusahaan yang menjual jasa adalah perusahaan yang bergerak dibidang koperasi simpan pinjam. Koperasi adalah suatu perusahaan yang kegiatan usahanya menghimpun dan menyalurkan dana kepada para anggotanya dengan bunga rendah. Koperasi ini di sebut juga sebagai koperasi kredit di mana pengelolaannya dilakukan secara mandiri dan demokratis, serta para anggotanya bergabung secara sukarela.Ada juga menyebutkan koperasi simpan pinjam adalah lembaga keuangan non-bank yang memiliki kegiatan usaha menerima simpanan anggotanya dan memberikan pinjaman uang kepada para anggota dengan bunga rendah.

Menurut Kasmir (2007:164) dalam memasarkan produknya, seorang pemasar harus pandai membaca situasi pasar sekarang dan di masa yang akan datang. Artinya pemasar harus cepat tanggap apa yang diinginkan dan dibutuhkan kosumen, kapan dan Pengaruh Bauran Pemasaran Jasa Terhadap Keputusan Nasabah Dalam Memilih CU Cinta Kasih 31 Tigapanah.

Oleh : Refi Mariska, Darna Sitanggang 
dimana dibutuhkannya. Dalam hal ini produsen harus menciptakan produk sesuai dengan keinginan dan kebutuhan kosumen secara tepat waktu.Di samping itu seorang pemasar harus mampu mengkomunikasikan keberadaan dan kelebihan produk dibandingkan dengan produk lainnya dari pesaing. Keputusan untuk membeli suatu produk baik barang maupun jasa timbul karena adanya dorongan emosional dari dalam diri maupun pengaruh dari luar. Proses keputusan pembelian merupakan proses psikologis dasar yang memainkan peranan penting dalam memahami bagaimana konsumen benar-benar membuat keputusan pembelian mereka. Keputusan konsumen salah satu yang mempengaruhi keputusan konsumen adalah bauran pemasaran.

Bauran pemasaran adalah kombinasi dari variabel atau kegiatan yang merupakan inti dari sistem pemasaran. Atau dengan kata lain, bauran pemasaran merupakan kumpulan variabel-variabel yang dapat digunakan perusahaan untuk mempengaruhi tanggapan konsumen.Bauran pemasaran terintegrasi yang terdiri dari 7P (product, price, place, promotion, people, process, physical evidence). Produk (product), adalah mengelola unsur produk termasuk perencanaan dan pengembangan produk atau jasa yang tepat untuk dipasarkan.Harga (price), adalah suatu sistem manajemen perusahaan yang akan menentukan harga dasar yang tepat bagi produk atau jasa dan harus menentukan strategi yang menyangkut potongan harga, pembayaran ongkos angkut dan berbagi variabel yang bersangkutan. Distribusi (place), yakni memilih dan mengelola saluran perdagangan yang dipakai untuk menyalurkan produk atau jasa dan juga untuk melayani pasar sasaran, serta mengembangkan sistem distribusi untuk pengiriman dan perniagaan produk secarafisik.

Promosi (promotion), adalah suatu unsur yang digunakan untuk memberitahukan dan membujuk pasar tentang produk atau jasa yang baru pada perusahaan melalui iklan, penjualan pribadi, promosi penjualan, maupun publikasi.Sarana fisik (Physical Evidence), merupakan hal nyata yang turut mempengaruhi keputusan konsumen untuk membeli dan menggunakan produk atau jasa yang ditawarkan.Unsur yang termasuk dalam sarana fisik.Orang (People), adalah semua pelaku yang memainkan peranan penting dalam penyajian jasa sehingga dapat mempengaruhi persepsi pembeli.Proses (Process), adalah semua prosedur aktual, mekanisme, dan aliran aktivitas yang digunakan untuk menyampaikan jasa.

Berdasarkan penjelasan di atas, maka dapat disimpulkan bahwa bauran pemasaran memiliki elemen-elemen yang sangat berpengaruh dalam penjualan karena elemen tersebut dapat mempengaruhi minat konsumen dalam melakukan keputusan pembelian.

Penelitian yang dilakukan Marlius (2016), melakukan penelitian tentang "pengaruh bauran pemasaran jasa terhadap keputusan nasabah menabung pada Bank Nagari Cabang Muaralabuh", menunjukkan bahwa harga, promosi, lokasi, proses berpengaruh positif dan signifikan secara parsial terhadap keputusan nasabah menabung pada Bank Nagari Cabang Muaralabuh, dan orang, bukti fisik, dan produk tidak berpengaruh positif dan signifakan terhadap keputusan nasabah menabung pada Bank Nagari Cabang Muaralabuh, sedangkan secara simultan bauran pemasaran berpengaruh positif dan signifikan terhadap keputusan nasabah menabung pada bank nagari cabang muaralabuh.

Seperti yang di jelaskan oleh Kotler dan Armstrong (2012 :62) dalam bauran pemasaran setidaknya ada 4 (empat) cara yang harus dilakukan oleh setiap pelaku usaha yang ingin menjadi pemenang pasar, keempat cara tersebut ialah produk(product)adalah setiap apa saja yang bisa ditawarkan di pasaruntuk mendapat perhatian, permintaan, atau konsumsi yang dapat memenuhi keinginan atau kebutuhan. Harga(price)merupakan faktor penting dalam bauran pemasaran dan menentukan ranah pemasaran yang diolakasikan oleh sebuah perusahaan. keempat faktor yang menentukan marketing mix, harga merupakan satusatunya unsur yang memberikan pemasukan atau pendapatan bagi perusahaan. Lokasi (place) adalah tempat perusahaan beroperasi atau tempat perusahaan melakukan kegiatan

Pengaruh Bauran Pemasaran Jasa Terhadap Keputusan Nasabah Dalam Memilih CU Cinta Kasih 32 Tigapanah.

Oleh : Refi Mariska, Darna Sitanggang 
untuk menghasilkan barang atau jasa yang mementingkan segi ekonominya.Dan yang terakhir adalah promosi (promotion) dalam kegiatan ini setiap perusahaan berusaha mempromosikan seluruh produk atau jasa yang dimilikinya baik secara langsung maupun tidak langsung.Tanpa promosi jangan diharapkan pelanggan dapat mengenal produk atau jasa yang ditawarkan.

Peranan koperasi simpan pinjam dalam era pembangunan yang terus menerus berlangsung ternyata amatlah penting untuk terus ditingkatkan, apalagi dalam era globalisasi sekarang ini. Dimana pembangunan yang dijalankan untuk membawa perubahan dan pertumbuhan yang fundamental dimana sektor perkoperasian akan menjadi berperan dominan yang di tunjang oleh sektor dana pihak ketiga. Akibat semakin ketatnya persaingan di dunia perkoperasian,

Keuntungan koperasi dapat diperoleh dari suku bunga pinjaman nasabah. Semakin banyak nasabah yang meminjam maka semakin banyak pula keuntungan yang akan di dapatkan. Untuk itu CU Cinta Kasih Tigapanah dituntut memperluas market share-nya untuk mendapat keuntungan atau laba yang tinggi dan agar tidak kalah dengan koperasi lain.Dalam mepertahankan kelangsungan hidup suatu usaha dibutuhkan strategi pemasaran yang efisien dan sesuai. Oleh karena itu pemasaran menjadi suatu hal yang terpenting dalam menjalankan suatu usaha, sehingga tujuan-tujuan dari usaha tersebut dapat tercapai. Keadaan pinjaman padaCU Cinta Kasih Tigapanah dapat di lihat dari tabel berikut :

Tabel 1 Data Jumlah Pencairan pinjamanCU Cinta Kasih TigapanahTahun 2017 - 2018

\begin{tabular}{|c|c|c|c|}
\hline Bulan & Jumlah pinjaman & Bulan & Jumlah pinjaman \\
\hline Desember & 22.400 .000 & September & 2.187 .100 .000 \\
\hline Januari & 2.787 .625 .000 & Oktober & 2.264 .440 .000 \\
\hline Fabruari & 2.528 .330 .000 & November & 1.505 .450 .000 \\
\hline Maret & 1.641 .180 .000 & Desember & 1.050 .400 .000 \\
\hline April & 2.050 .420 .000 & Januari & 2.160 .000 .000 \\
\hline Mei & 2.019 .440 .000 & Februari & 2.143 .620 .000 \\
\hline Juni & 1.664 .480 .000 & Maret & 1.478 .370 .000 \\
\hline Juli & 1.960.200.000 & April & 1.429 .780 .000 \\
\hline Agustus & 2.368.070.000 & MeiK S & 1.664 .750 .000 \\
\hline
\end{tabular}

Sumber: CU Cinta Kasih Tigapanah.

Dari tabel diatas di ketahui bahwa jumlah pencairan pinjaman CU Cinta Kasih Tigapanah pada tahun 2017-2018 mengalami fluktuasi di bulan-bulan tertertu yang jumlahnya cukup besar yaitu pada bulan Januari 2017, Februari 2017 dan Agustus 2017sedangkan pada bulan yang lainnya yaitu pada bulan Desember 2017, Desember 2018, April 2018 dan Mei 2018 rendah. Sehingga dapat dikatakan bahwa keputusan nasabah memilih CU. Cinta Kasih Tigapanahcenderung tidak stabil. Artinya ada masalah yang dihadapi perusahaan sehingga mengakibatkan penurunan maupun kenaikan jumlah pinjaman nasabah. Fluktuasi ini juga diakibatkan oleh adanya beberapa ketentuan umum dari CU Cinta Kasih Tigapanahyaitu yang bisa mengajukan pinjaman adalah anggota yang sudah mengikuti pendidikan wajib Credit Union kecuali pinjaman kapitalisasi, di tambah pinjaman yang melebihi jumlah simpanan akan diproses dalam waktu 14 hari.Hal ini dapat menyebabkan naik turunnya niat konsumen untuk melakukan transaksi pada CUCinta Kasih Tigapanah. CU Cinta Kasih Tigapanah juga hanya melakukan promosi mulut ke mulut dan memiliki produk hanya 2 macam yaitu simpanan pokok dan tabungan investasi/simpanan sukarela.Oleh karena itu diperlukan pemahaman yang serius dari pihak manajemen terhadap strategi pemasaran yang ada pada CUCinta Kasih Tigapanahuntuk meningkatkan keputusan Nasabah untuk memilih CUCinta Kasih Tigapanah.

Pengaruh Bauran Pemasaran Jasa Terhadap Keputusan Nasabah Dalam Memilih CU Cinta Kasih 33

Tigapanah.

Oleh : Refi Mariska, Darna Sitanggang 
Pada CU Cinta Kasih Tigapanah produk yaitu tabungan dan pinjaman.Tabungan yang ditawarkan ada 2 jenis yang dibedakan berdasarkan waktu penarikan yang dilakukan oleh nasabah. Dan Pada CU Cinta Kasih Tigapanah biaya administrasi yang ditawarkan rendah dibandingkan dengan usaha sejenisnya, walaupun demikian bunga yang ditawarkan sama dengan usaha sejenis lainnya. Lokasi CU Cinta Kasih Tigapanah strategis dan banyak angkutan umum menuju lokasi, serta lokasi parkir yang luas.Pada CU Cinta Kasih Tigapanah hanya mengandalkan promosi WOM (Word Of Mouth) atau promosi dari mulut ke mulut yang artinya pemberian rekomendasi dari salah seorang pelanggan yang puas terhadap salah satu produk kepada individu lain. Dan Pada CU Cinta Kasih Tigapanah bangunan yang digunakan sudah cukup tua namun terawat.Serta CU Cinta Kasih Tigapanah mengharuskan seluruh karyawan untuk ramah terhadap seluruh nasabah yang datang, dan didatangi, serta cepat melayani keluhan nasabah.Pada CU Cinta Kasih Tigapanah menetapkan standar dalam menanggapi nasabah, dan CU Cinta Kasih Tigapanah menangani sesuai dengan aturan yang diberlakukan.

\section{Bauran Pemasaran}

\section{KAJIAN TEORITIS}

Bauran pemasaran adalah kombinasi dari variabel atau kegiatan yang merupakan inti dari sistem pemasaran. Atau dengan kata lain, bauran pemasaran merupakan kumpulankumpulan variabel-variabel yang dapat digunakan perusahaan untuk mempengaruhi tanggapan konsumen. Untuk mencapai tujuan pemasaran, maka komponen bauran pemasaran harus saling mendukung satu dengan yang lainnya, atau dengan kata lain, manajemen harus berusaha agar komponen komponen bauran pemasaran itu dapat terpadu untuk mencapai tujuan yang telah ditetapkan perusahaan. Jadi dengan bauran pemasaran itu akan dapat ditentukan tingkat keberhasilan pemasaran yang diikuti kepuasan konsumen. Untuk membuat direferensiasi tersebut efektif, perusahaan harus mengembangkan suatu bauran pemasaran yang tetap. Bauran pemasaran terintegrasi yang terdiri dari 7P (product, price, place, promotion, people, process, physical evidence) (Kotler dan Amstrong, 2012).

\section{Produk (Product).}

Produk adalah segala sesuatu yang dapat ditawarkan pada pasar agar menarik perhatian, akusisi, penggunaan atau konsumsi yang dapat memuaskan suatu keinginan atau kebutuhan. Selanjutnya, produk dalam arti luas meliputi objek-objek fisik, jasa, cara, orang, tempat, organisasi, ide atau bauran entitas-entitas ini (Kotler dan Amstrong, 2012). "Produk dalam pengertian umum adalah segala sesuatu yang dapat ditawarkan ke pasar untuk mendapat perhatian, dibeli, dipergunakan atau dikonsumsidan dapat memuaskan keinginan dan kebutuhan (Nana, 2015)."

Maka dapat disimpulkan bahwa produk adalah segala sesuatu yang dapat ditawarkan kepada konsumen untuk memenuhi kebutuhan dan keinginan konsumen.

\section{Indikator Produk}

Kualitas produk memiliki dimensi yang dapat digunakan untuk menganalisis karakteristik dari suatu produk. Menurut Garvin dalam buku Tjiptono (2016) kualitas produk memiliki delapan indikator sebagai berikut:

1. Performance (kinerja), merupakan karakteristik operasi pokok dari produk inti (core product) yang dibeli.

2. Features (fitur atau ciri-ciri tambahan), yaitu karaktersitik sekunder atau pelengkap.

3. Reliability (reliabilitas), yaitu kemungkinan kecil akan mengalami kerusakan atau gagal dipakai.

Pengaruh Bauran Pemasaran Jasa Terhadap Keputusan Nasabah Dalam Memilih CU Cinta Kasih 34

Tigapanah.

Oleh : Refi Mariska, Darna Sitanggang 
4. Confermance to Specifications (kesesuaian dengan spesifikasi), yaitu sejauh mana karakteristik desain dan operasi memenuhi standar-standar yang telah ditetapkan sebelumnya.

5. Durability (daya tahan), yaitu berkaitan dengan berapa lama produktersebut dapat digunakan.

6. Serviceability(kemampuan melayani), meliputi kecepatan, kompetensi, kenyamanan, kemudahan direparasi; serta penanganan keluhan secara memuaskan.

7. Esthetics (Estetika), yaitu daya tarik produk terhadap panca indera.

8. Perceived Quality (kualitas yang dipersepsikan), yaitu citra dan reputasi produk serta tanggung jawab perusahaan terhadapnya.

\section{Harga}

Harga merupakan faktor penting dalam bauran pemasaran dan menentukan ranah pemasaran yang dialokasikan oleh sebuah perusahaan. Ketujuh faktor yang menentukan marketing mix, harga merupakan satu-satunya unsur yang memberikan pemasukan atau pendapatan bagi perusahaan.

Menurut Tjiptono (2016) bahwa harga merupakan satu-satunya unsur bauran pemasaran yang mendatangkan pemasukan atau pendapatan bagi perusahaan.Sedangkan menurut Alma (2013:169), mengemukakan bahwa harga adalah nilai suatu barang yang dinyatakan dengan uang.Berdasarkan beberapa definisi diatas maka dapat diketahui bahwa harga adalah nilai dari suatu produk dalam bentuk uang yang harus dikorbankan ataudikeluarkan oleh konsumen guna mendapatkan produk yang diinginkan, sedangkan bagi produsen atau pedagang harga dapat menghasilkan pendapatan atau sebagai pemasukan bagi produsen tersebut.

\section{Indikator Harga}

Indikator harga menurut Mursid (2014) adalah sebagai berikut:

1. Harga yang kompetitif yaitu harga yang ditawarkan lebih kompetitif dari pesaing.

2. Kesesuaian harga dengan harga pasar yaitu harga yang ditawarkan sesuai dari kebutuhan konsumen.

3. Kesesuaian harga dengan kualitas produk yaitu harga yang ditawarkan sesuai dengan kualitas produk.

4. Angsuran yaitu pembayaran yang bisa diangsur sampai jangka waktu tertentu.

\section{Lokasi}

. Lokasi usaha dapat juga disebut dengan saluran distribusi perusahaan karena lokasi juga berhuungan langsung dengan pembeli atau konsumen. Lokasi akan mempengaruhi pertumbuhan di masa depan. Area yang dipilih haruslah mampu untuk tumbuh dari segi ekonomi sehingga ia dapat mempertahankan kelangsungan hidup baik itu dalam usaha perdagangan eceran ataupun lainnya.

Lokasi menurut Tjiptono (2016) Lokasi mengacu pada berbagai aktivitas pemasaran yang berusaha memperlancar dan mempermudah penyampaian atau penyaluran barang dan jasa dari produsen kepada konsumen. Sedangkan menurut Kotler dan Amstrong (2012 "place include company activities that make the product available to target consumers". Kemudian menurut Lupiyoadi dan Hamdani (2011) "lokasi adalah keputusan yang dibuat perusahaan atau instansi pendidikan berkaitan dengan di mana operasi dan stafnya akan ditempatkan".

Maka dapat disimpulkan bahwa lokasi adalah tempat produsen menyalurkan produknya kepada konsumen ataupun merupakan komitmen sumber daya jangka panjang.

Pengaruh Bauran Pemasaran Jasa Terhadap Keputusan Nasabah Dalam Memilih CU Cinta Kasih 35

Tigapanah.

Oleh : Refi Mariska, Darna Sitanggang 


\section{Indikator Lokasi}

Indikator lokasi menurut Tjiptono (dalam Kuswatiningsih, 2016) sebagai berikut :

1. Akses, Misalnya lokasi yang sering dilalui atau mudah dijangkau sarana transportasi.

2. Visibilitas, Yaitu lokasi atau tempat yang dapat dilihat dengan jelas dari jarak pandang normal.

3. Lalu lintas (traffic),

4. Tempat parkir yang luas, nyaman, dan aman baik untuk kendaraan roda dua maupun roda empat.

5. Ekspansi, yaitu tersedianya tempat yang cukup luas apabila ada perluasan dikemudian hari.

6. Lingkungan, yaitu daerah sekitar yang mendukung produk yang ditawarkan. Sebagai contoh, restoran atau rumah makan berdekatan dengan daerah pondokan, asrama, kampus, sekolah, perkantoran, dan sebagainya.

7. Persaingan (lokasi pesaing), Sebagai contoh, dalam menentukan lokasi restoran perlu dipertimbangkan apakah di jalan atau daerah yang sama terdapat restoran lainnya.

\section{Promosi}

Promosi memegang peranan penting dalam menghubungkan jarak antar produsen dengan konsumen.Kegiatan promosi ini tidak bisa dilakukan secara sembarangan karenadapat mempengaruhi kelangsungan hidup perusahaan dalam jangka panjang.Menurut Tjiptono (2016) "promosi merupakan elemen bauran pemasaran yang berfokus pada upaya menginformasikan, membujuk, dan mengingatkan kembali kepada konsumen akan merek dan produk perusahaan".Kemudian menurut Hermawan (2012) "promosi adalah salah satu komponen prioritas dari kegiatan pemasaran yang memberitahukan kepada konsumen bahwa perusahaan meluncurkan produk baru yang menggoda konsumen untuk melakukan pembelian".

Maka dapat disimpulkan promosi adalah elemen bauran pemasaran yang memberitahukan kepada konsumen bahwa perusahaan meluncurkan produk yang menggoda konsumen untuk membeli dan untuk mengingat kan kembali kepada konsumen akan merek dan produk perusahaan.

\section{Indikator Promosi}

Menurut Kotlerdan Keller (2007) indikator-indikator promosi diantaranya adalah:

1. Frekuensi promosi adalah jumlah promosi penjualan yang dilakukan dalam suatu waktu melalaui media promosi penjualan

2. Kualitas promosi adalah tolak ukur seberapa baik promosi penjualan dilakukan.

3. Kuantitas promosi adalah nilai atau jumlah promosi penjualan yang diberikan konsumen.

4. Waktu promosi adalah lamanya promosi yang dilakukan oleh perusahaan.

5. Ketepatan atau kesesuaian sasaran promosi merupakan faktor yang diperlukan untuk mencapai target yang diinginkan perusahaan

\section{Orang (People)}

Menurut Zeithaml and Bitner dalam Hurriyati (2005) "People of all human actor who pay in service delivery and thus influence the buyer's perceptions : namely, the firm's personel, the customer and other customers in the service environment". Orang (people) adalah semua pelaku yang memainkan peranan dalam penyajian jasa sehingga dapat mempengaruhi persepsi pembeli. Elemen-elemen dari people adalah pegawai perusahaan, konsumen, dan konsumen lain dalam lingkungan jasa.

Pengaruh Bauran Pemasaran Jasa Terhadap Keputusan Nasabah Dalam Memilih CU Cinta Kasih 36

Tigapanah.

Oleh : Refi Mariska, Darna Sitanggang 
Sedangkan, menurut Setyaningrum, dkk (2015) dimensi people memiliki peran besar dalam penyampaian jasa yang merupakan aksi, kinerja, dan pengalaman.Pembawaan atau penampilan dan keahlian personel jasa mempengaruhi jasa yang diterima oleh konsumen.Dalam hubungannya dengan pemasaran jasa, maka people yang berfungsi sebagai penyedia jasa sangat mempengaruhi kualitas jasa yang diberikan.

Keputusan dalam people ini berarti sehubungan dengan seleksi, pelatihan, motivasi dan manajemen sumber dayamanusia.

\section{Indikator People}

Menurut Akbar (2011) mengukur people dapat dilakukan dengan menggunakan indikator-indikator sebagai berikut :

1. Kompetensi, yaitu orang-orang yang bertugas dapat melakukan tugasnya dengan sangat handal serta penuh keahlian pada bidangnya masing- masing.

2. Kesopanan, yaitu orang-orang yang memberikan jasa selalu bersikap ramah, baik, sopan kepadakonsumen.

3. Selektif, yaitu orang-orang yang menjadi penyaji jasa sebelum di pekerjakan harus memenuhi syarat yang telah ditetapkan oleh masing- masing perusahaan penyediajasa.

4. Komunikatif, yaitu orang-orang yang menyajikan jasa akan selalu memberikan informasi penting yang akan disampaikan kepada konsumen.

\section{Proses (Process)}

Process menurut Zeithaml and Bitner dalam Hurriyati (2005) adalah "The actual procedures, mechanism, and flow of activities by which the service is delivered the service delivery operating system". Proses adalah semua prosedur aktual, mekanisme dan aliran aktivitas yang digunakan untuk menyampaikan jasa. Menurut Setyaningrum, dkk (2015:304) proses meliputi rangkaian kegiatan yang dilalui oleh konsumen dalam mengonsumsi jasa. Pengelola jasa menghadapi tantangan bagaimana menciptakan setiap tahapan jasa yang diberikan berjalan baik. Jadi, dapat disimpulkan bahwa proses dalam jasa merupakan gabungan semua aktivitas, umumnya terdiri dari prosedur, jadwal pekerjaan, mekanisme, aktivitas dan hal-hal rutin, di mana jasa dihasilkan dan disampaikan kepada konsumen.

Indikator Proses.

Menurut Mursid (2006) indikator yang berkaitan dengan proses, yaitu sebagai berikut:

1. Kecepatan, yaitu penyedia jasa memberikan segala proses yang cepat dalam menyampaikan jasa yang akan dikonsumsi oleh konsumen sehingga konsumen tidak berlarut-larut menunggu jasa yang akan diperolehnya.

2. Kemudahan, yaitu penyedia jasa menyusun prosedur yang mudah dalam mengkonsumsi jasa bagi konsumen.

3. Ketelitian, yaitu dalam menyampaikan jasa yang disediakan oleh penyedia jasa tampak benar-benar teliti dalam setiap aktivitas pemberian jasa tersebut.

4. Penyampaian Terhadap Keluhan, yaitu penyedia jasa menanggapi keluhan yang masuk dari konsumen dengan baik serta memberikan solusi terhadap permasalahan konsumen tersebut.

\section{Physical Evidence}

Bukti Fiski menurut Zeithaml and Bitner dalam Hurriyati (2005) " The environment in which the service is delivered and where firm and customer interact and any tangible component that facilitate performance or communication of the service". Bukti fisik ini merupakan suatu hal yang secara nyata turut mempengaruhi keputusan konsumen untuk membeli dan menggunakan produk jasa yang ditawarkan.Unsur-unsur yang termasuk di dalam bukti fisik antara lain Pengaruh Bauran Pemasaran Jasa Terhadap Keputusan Nasabah Dalam Memilih CU Cinta Kasih 37 Tigapanah.

Oleh : Refi Mariska, Darna Sitanggang 
lingkungan fisik, dalam hal ini bangunan fisik, perlatan, perlengkapan, logo, warna dan barang-barang lainnya yang disatukan dengan service yang diberikan seperti tiket, sampul, label dan lain sebagainya.

Sementara itu, Setyaningrum, dkk (2015) menjelaskan bahwa bukti secara fisik merupakan aspek penting dari jasa, sebab sebagian produk jasa konsumen perlu hadir secara fisik dalam lingkungan jasa.Kualitas lingkungan jasa yang baik secara langsung mempengaruhi kepuasan konsumen terhadap jasa yang diterima. Lingkungan jasa yang nyaman dan sesuai target pasar yang dituju juga akan membuat konsumen bersedia menghabiskan lebih banyak waktu atau lebih sering mengunjungi outlet jasa.

\section{Indikator PhysicalEvidence}

Bukti fisik ini merupakan suatu hal yang secara nyata turut mempengaruhi keputusan konsumen untuk membeli dan menggunakan produk jasa yang ditawarkan

Menurut Assauri (2010) Indikator bukti fisik yang baik yaitu, sebagai berikut:

1. Lingkungan, yaitu lingkungan dengan kondisi yang nyaman serta menarik pada internal maupun eksternal lokasi usaha.

2. Tata Letak, yaitu berkaitan dengan penataan lokasi yang baik dan enak dilihat

3. Fasilitas Tamabahan, yaitu dengan memberikan fasilitas-fasilitas pendukung untuk memberikan kenyamanan bagikonsumen.

\section{Proses Keputusan Pembelian}

Keputusan untuk membeli suatu produk baik barang maupun jasa timbul karena adanya dorongan emosional dari dalam diri maupun pengaruh dari luar. Proses keputusan pembelian merupakan proses psikologis dasar yang memainkan peranan penting dalam memahami bagaimana konsumen benar-benar membuat keputusan pembelian mereka. Proses keputusan pembelian model lima tahap menurut Kotler dan Armstong (2012) adalah sebagai berikut: (1) Pengenalan masalah, (2) Pencarian informasi, (3) Evaluasi alternatif, (4) Keputusan pembelian, dan (5) Perilaku pasca pembelian

\section{Indikator Keputusan Pembelian}

Kotler \& Armstrong (2016) mengemukakan keputusan pembelian memiliki indikator sebagai berikut:

1. Pilihan produk, Konsumen dapat mengambil keputusan untuk membeli sebuah produk atau menggunakan uangnya untuk tujuan yang lain.

2. Pilihan merek, Konsumen harus mengambil keputusan tentang merek nama yang akan dibeli setiap merek memiliki perbedaan tersendiri.

3. Pilihan penyalur. Konsumen harus mengambil keputusan tentang penyalur mana yang akan dikunjungi.

4. Waktu pembelian. Keputusan konsumen dalam pemilihan waktu pembelian bisa berbeda-beda misalnya ada yang membeli setiap hari, satu minggu sekali, dua minggu sekali dan lain sebagainya.

5. Jumlah pembelian. Konsumen dapat mengambil keputusan tentang seberapa banyak produk yang akan dibelanjakan pada suatu saat.

6. Metode pembayaran. Konsumen dapat mengambil keputusan tentang metode pembayaran yang akan dilakukan dalam pengambilan keputusan menggunakan produk atau jasa.

Menurut Akbar dan Nizar (2011) indikator keputusan pembelian adalah sebagai berikut:

1. Yakin dalam membeli.

Pengaruh Bauran Pemasaran Jasa Terhadap Keputusan Nasabah Dalam Memilih CU Cinta Kasih 38

Tigapanah.

Oleh : Refi Mariska, Darna Sitanggang 
2. Mencari informasi.

3. Merencanakan pembelian.

4. Sesuai keinginan.

Berdasarkan beberapa pendapat ahli di atas indikator yang digunakan untuk variabel keputusan nasabah adalah teori yang dikemukan oleh Kotler dan Armstrong (2012) yaitu pilihan produk, pilihan merek, pilihan penyalur, waktu pembelian, jumlah pembelian dan metode pembelian.

\section{METODE PENELITIAN}

Populasi dalam penelitian ini adalah nasabah pengguna jasa CU Cinta Kasih Tigapanah selama tahun 2015-2018 yang berjumlah 10.500 orang. Jumlah sampel sebanyak 96 orang dengan tingkat keyakinan ditetapkan 95\% $(\alpha=5 \%)$.

\section{Operasionalisasi Variabel}

Tabel 2.Operasinalisasi Variabel

\begin{tabular}{|l|l|l|l|l|}
\hline NO & VARIABEL & DEFENISI SIUDI & INDIKATOR \\
VARIABEL & SKALA \\
UKUR
\end{tabular}

Pengaruh Bauran Pemasaran Jasa Terhadap Keputusan Nasabah Dalam Memilih CU Cinta Kasih 39 Tigapanah.

Oleh : Refi Mariska, Darna Sitanggang 
Volume 21 Nomor 1, Maret 2021

\begin{tabular}{|c|c|c|c|c|}
\hline NO & VARIABEL & DEFENISI & \begin{tabular}{|l|} 
INDIKATOR \\
VARIABEL \\
\end{tabular} & $\begin{array}{l}\text { SKALA } \\
\text { UKUR }\end{array}$ \\
\hline & & $\begin{array}{l}\text { akan merek dan produk } \\
\text { perusahaan }\end{array}$ & & \\
\hline 5 & Orang $\left(X_{5}\right)$ & $\begin{array}{l}\text { semua pelaku yang memainkan } \\
\text { peranan dalam penyajian jasa } \\
\text { sehingga dapat mempengaruhi } \\
\text { persepsi pembeli }\end{array}$ & $\begin{array}{ll}\text { a. } & \text { Kompetensi } \\
\text { b. } & \text { Kesopanan } \\
\text { c. } & \text { Selektif } \\
\text { d. } & \text { Komunikatif } \\
\end{array}$ & Skala Likert \\
\hline 6 & Proses $\left(\mathrm{X}_{6}\right)$ & $\begin{array}{l}\text { Proses dalam jasa merupakan } \\
\text { gabungan semua aktivitas, } \\
\text { umumnya terdiri dari } \\
\text { prosedur, jadwal pekerjaan, } \\
\text { mekanisme, aktivitas dan hal- } \\
\text { hal rutin, di mana jasa } \\
\text { dihasilkan dan disampaikan } \\
\text { kepada konsumen }\end{array}$ & $\begin{array}{ll}\text { a. } & \text { Kecepatan } \\
\text { b. } & \text { Kemudahan } \\
\text { c. } & \text { Ketelitian } \\
\text { d. } & \text { Penyampaian } \\
& \text { terhadap keluhan }\end{array}$ & Skala Likert \\
\hline 7 & $\begin{array}{l}\text { Bukti fisik } \\
\left(X_{7}\right)\end{array}$ & $\begin{array}{l}\text { Bukti fisik ini merupakan suatu } \\
\text { hal yang secara nyata turut } \\
\text { mempengaruhi keputusan } \\
\text { konsumen untuk membeli dan } \\
\text { menggunakan produk jasa } \\
\text { yang ditawarkan }\end{array}$ & $\begin{array}{l}\text { a. Lingkungan } \\
\text { b. Tata letak } \\
\text { c. Fasilitas tambahan }\end{array}$ & \\
\hline 8 & $\begin{array}{l}\text { Keputusa } \\
\mathrm{n} \text { nasabah } \\
(\mathrm{Y})\end{array}$ & $\begin{array}{l}\text { Tindakan yang dilakukan } \\
\text { konsumen } \\
\text { menggunakan produk atau jasa } \\
\text { CU Cinta Kasih Tigapanah }\end{array}$ & $\begin{array}{ll}\text { a. } & \text { Pilihan produk } \\
\text { b. } & \text { Pilihan merek } \\
\text { c. } & \text { Pilihan penyalur } \\
\text { d. Waktu pembelian } \\
\text { e. Jumlah pembelian } \\
\text { f. Metode } \\
\text { pembayaran }\end{array}$ & Skala likert \\
\hline
\end{tabular}

\section{Teknik Analisis Data}

\section{Metode Analisis Regresi Berganda}

Metode analisi yang digunakan dalam penelitian adalah analisis regresi linear berganda dengan persamaan sebagai berikut:

$$
Y=a+b_{1} X_{1}+b_{2} X_{2}+b_{3} X_{3+} b_{4} X_{4+} b_{5} X_{5+} b_{6} X_{6}+b_{7} X_{7}+e
$$

\section{Uji Hipotesis}

Untuk mengetahui pengaruh bauran pemasaran jasa (produk, harga,lokasi, promosi, orang, proses dan bukti fisik) terhadap keputusan nasabah dalam memilih CU Cinta Kasih Tigapanah, dilakukan dengan Uji F mengetahui pengaruh variabel produk, harga, lokasi, promosi, orang, proses dan bukti fisik secara simultan terhadap keputusan nasabah dalam memilih CU Cinta Kasih Tigapanah dan Uji t untuk mengetahui pengaruh bauran pemasaran jasa (produk, harga, lokasi, promosi, orang, proses dan bukti fisik) secara parsial terhadap keputusan nasabah memilih CU Cinta Kasih Tigapanah.

\section{Koefisien determinasi $\left(\mathbf{R}^{2}\right)$}

Koefisien determinasi $\left(\mathrm{R}^{2}\right)$ pada intinya mengukur seberapa besar kemampuan model dalam menerangkan variabel terikat. Jika $\mathrm{R}^{2}$ semakin besar (mendekati satu), maka Pengaruh Bauran Pemasaran Jasa Terhadap Keputusan Nasabah Dalam Memilih CU Cinta Kasih 40 Tigapanah. 
kemampuan variabel bebas $(\mathrm{X})$ dalam menjelaskan variabel terikat $(\mathrm{Y})$ semakin besar. Hal ini berarti model yang digunakan semakin kuat untuk menerangkan variasi variabel terikat dan sebaliknya.

\section{HASIL PENELITIAN DAN PEMBAHASAN}

\section{Sejarah Ringkas CU Koperasi Cinta Kasih Tigapanah}

CU Koperasi Cinta Kasih Tigapanah adalah salah satu koperasi kredit/credit union di Indonesia yang berkantor pusat dijalan Sukanalu No 02 Tigapanah, Karo Sumatra Utara. Sebagai CU Yang berkembang, CU Cintah Kasih secara terus menerus akan konsisten untuk memberikan pelayanan terbaiknya bagi seluruh lapisan masyarakat di Sumatera Utara. Koperasi CU Cinta Kasih berdiri pada tanggal 31 maret 1989 pada siding paripurna dewan paroki Tigapanah, keprihatinan para pengurus gereja katolik saat itu kepada umat katolik diparoki Tigapanah yang mayoritas peteni bertekad untuk mendirikan koperasi yang diberi nama "Credit Union Cinta Kaih". Untuk pertama kalinya 21 orang pengurus gereja katolik menjadi anggotanya.

Kopdit CU Cinta Kasih juga merupakan lembaga yang terus berkembang dan menjalin hubungan kerja dengan beberapa lembaga keuangan seperti perbankan, Notaris, Inkopdit Jakarta, dan PUSKOPDIT Karo Simalem Lestari dibidang pendidikan bagi karyawan maupun pengurus, kerja sama tersebut dibutuhkan untuk kelancaran dan kemudahan cash flow, pendidikan dan ekonomi. Lembaga Kopdit CU Cinta Kasih juga bekerja sama dibidang teknologi dan informasi,seiring dengan meningkatnya jumlah anggota dan transaksi yang terjadi maka dibutuhkan pula teknologi sebagai faktor support utama dalam operasional yang terjadi.

\section{Pengujian Hipotesis}

Pengujian Secara Simultan (Uji F)

Tabel 3ANOVA UJI F

\begin{tabular}{|l|l|r|r|r|r|c|}
\hline \multicolumn{1}{|l|}{ Model } & Sum of Squares & \multicolumn{1}{c|}{ Df } & Mean Square & F & Sig. \\
\hline \multirow{3}{*}{1} & Regression & 576.692 & 7 & 82.385 & 73.497 & $.000^{\mathrm{b}}$ \\
\cline { 2 - 7 } & Residual & 98.642 & 88 & 1.121 & & \\
\cline { 2 - 7 } & Total & 675.333 & 95 & & & \\
\hline
\end{tabular}

Sumber : Data diolah dengan SPSS

Berdasarkan output SPSS pada tabel 3 dapat dilihat bahwa bahwa terdapat pengaruh yang signifikan antara variabel bebas yaitu produk, harga, lokasi, promosi, orang, proses, bukti fisik terhadap variabel terikat yaitu keputusan nasabah memilih CU Cinta Kasih Tigapanah.. Hal ini ditunjukkan dari nilai signifikan F sebesar 0,000<a $(0,05)$ sehingga dapat disimpulkan bahwa secara simultan variabel produk, harga, lokasi, promosi, orang, proses, bukti fisik berpengaruh dan signifikan terhadap keputusan nasabah memilih CU. Cinta Kasih Tigapanah sehingga dapat disimpulakan bahwa $\mathrm{H}_{0}$ ditolakdan $\mathrm{H}_{\mathrm{i}}$ diterima.

Pengujian Secara Parsial (Uji t)

Tabel 4 Hasil Uji t

\begin{tabular}{|c|c|c|c|c|c|}
\hline \multirow[b]{2}{*}{ Model } & \multicolumn{2}{|c|}{ Unstandardized Coefficients } & $\begin{array}{c}\text { Standardized } \\
\text { Coefficients }\end{array}$ & \multirow[b]{2}{*}{$\mathrm{t}$} & \multirow[b]{2}{*}{ Sig. } \\
\hline & B & Std. Error & Beta & & \\
\hline \begin{tabular}{|l|l|}
1 & (Constant)
\end{tabular} & 1.848 & 1.579 & & 1.170 & .245 \\
\hline
\end{tabular}

Pengaruh Bauran Pemasaran Jasa Terhadap Keputusan Nasabah Dalam Memilih CU Cinta Kasih 41 Tigapanah.

Oleh : Refi Mariska, Darna Sitanggang 
Volume 21 Nomor 1, Maret 2021

\begin{tabular}{|c|c|c|c|c|c|}
\hline \multirow[b]{2}{*}{ Model } & \multicolumn{2}{|c|}{ Unstandardized Coefficients } & \multirow{2}{*}{$\begin{array}{c}\begin{array}{c}\text { Standardized } \\
\text { Coefficients }\end{array} \\
\text { Beta } \\
\end{array}$} & \multirow[b]{2}{*}{$t$} & \multirow[b]{2}{*}{ Sig. } \\
\hline & B & Std. Error & & & \\
\hline Produk & .304 & .161 & .202 & 1.895 & .061 \\
\hline Harga & .091 & .125 & .053 & .724 & .471 \\
\hline Lokasi & .018 & .046 & .017 & .381 & .704 \\
\hline Promosi & .034 & .089 & .032 & .380 & .705 \\
\hline Orang & .354 & .147 & .256 & 2.407 & .018 \\
\hline Proses & .440 & .110 & .318 & 4.000 & .000 \\
\hline Bukti_Fisik & .237 & .143 & .138 & 1.650 & .103 \\
\hline
\end{tabular}

a. Dependent Variable: Keputusan_Nasabah

Sumber :Data diolah dengan SPSS

1. Berdasarkan out put SPSS pada Tabel 4 dapat dilihat bahwa variabel produk, nilai $t_{\text {hitung }}$ $1,895<1,98729$ dan tingkat signifikan sebesar $0,061>0,05$ sehingga $\mathrm{H}_{0}$ diterima dan $\mathrm{H}_{1}$ ditolak. Artinya, produk berpengaruh positif tetapi tidak signifikan terhadap keputusan nasabah memilih CU Cinta Kasih Tigapanah.

2. Untuk variabel harga, nilai uji $t_{\text {hitung }} 0,724<t_{\text {tabel }} 1,98729$ dan tingkat signifikan $0,471>$ 0,05 sehingga $\mathrm{H}_{0}$ diterima dan $\mathrm{H}_{1}$ ditolak. Artinya, harga berpengaruh positif tetapi tidak signifikanterhadap keputusan nasabah memilih CU Cinta Kasih Tigapanah.

3. Untuk variabel lokasi, nilai uji $t_{\text {hitung }} 0,381<t_{\text {tabel }} 1,98729$ dan tingkat signifikan $0,704>$ 0,05 sehingga $\mathrm{H}_{0}$ diterima dan $\mathrm{H}_{1}$ ditolak. Artinya, lokasi berpengaruh positif tetapi tidak signifikan terhadap keputusan nasabah memilih CU Cinta Kasih Tigapanah.

4. Untuk variabel promosi, nilai uji $\mathrm{t}_{\text {hitung } 0,380}<\mathrm{t}_{\text {tabel }} 1,98729$ dan-tingkat signifikan $0,705>$ 0,05 sehingga $\mathrm{H}_{0}$ diterima dan $\mathrm{H}_{1}$ ditolak. Artinya, promosi berpengaruh positif tetapi tidak signifikanterhadap keputusan nasabah memilih CU Cinta Kasih Tigapanah.

5. Untuk variabel orang, nilai uji $t_{\text {hitung }} 2,407>t_{\text {tabel }} 1,98729$ dan tingkat signifikan $0,018<$ 0,05 sehingga $\mathrm{H}_{0}$ ditolak dan $\mathrm{H}_{1}$ diterima. Artinya, orang berpengaruh positif dan signifikanterhadap keputusan nasabah memilih CU Cinta Kasih Tigapanah.

6. Untuk variabel proses, nilai uji thitung $4,000>\mathrm{t}_{\text {tabel }} 1,98729$ dan tingkat signifikan $0,000<$ 0,05 sehingga $\mathrm{H}_{0}$ ditolak dan $\mathrm{H}_{1}$ diterima. Artinya, proses berpengaruh positif dan signifikanterhadap keputusan nasabah memilih CU Cinta Kasih Tigapanah.

7. Untuk variabel bukti fisik, nilai uji $t_{\text {hitung }} 1,650<t_{\text {tabel }} 1,98729$ dan tingkat signifikan 0,103 $>0,05$ sehingga $\mathrm{H}_{0}$ diterima dan $\mathrm{H}_{1}$ ditolak. Artinya, bukti fisik berpengaruh positif tetapi tidak signifikanterhadap keputusan nasabah memilih CU Cinta Kasih Tigapanah.

\section{Persamaan Regresi Linear Berganda}

Hasil pengolahan data dengan menggunakan SPSS dapat dilihat pada table 5 di atas dengan model regresi linear berganda sebagai berikut:

$$
\mathrm{Y}=1,848+0,304 \mathrm{X} 1+0,091 \mathrm{X} 2+0,018 \mathrm{X} 3+0,034 \mathrm{X} 4+0,354 \mathrm{X} 5+0,440 \times 6+0,237 \mathrm{X} 7+\mathrm{e}
$$

1. Nilai 1,848 adalah nilai konstanta yang artinya apabila variabel $X$ (produk, harga, lokasi, promosi, orang, proses, bukti fisik) konstan atau tidak ada perubahan maka besarnya nilaivariabel Y (keputusan nasabah memilih CU Cinta Kasih Tigapanah) adalah sebesar 1,848 .

2. Nilai koefisien regresi variabel produk (X1) sebesar 0,304 artinya bila produk meningkat 1 satuan maka keputusan nasabah memilih CU Cinta Kasih Tigapanah (Y) akan naik sebesar 0,304 satuan.

Pengaruh Bauran Pemasaran Jasa Terhadap Keputusan Nasabah Dalam Memilih CU Cinta Kasih 42

Tigapanah.

Oleh : Refi Mariska, Darna Sitanggang 
3. Nilai koefisien regresi variabel harga (X2) sebesar 0,091 artinya bila harga meningkat 1 satuan maka keputusan nasabah memilih CU Cinta Kasih Tigapanah $(Y)$ akan naik sebesar 0,091 satuan.

4. Nilai koefisien regresi variabel lokasi (X3) sebesar 0,018 artinya bila lokasi meningkat 1 satuan maka keputusan nasabah memilih CU Cinta Kasih Tigapanah (Y) akan naik sebesar 0,018 satuan.

5. Nilai koefisien regresi variabel promosi (X4) sebesar 0,034 artinya bila promosi meningkat 1 persen maka keputusan nasabah memilih CU Cinta Kasih Tigapanah (Y) akan naik sebesar 0,034 satuan.

6. Nilai koefisien regresi variabel orang (X5) sebesar 0,354 artinya bila orangmeningkat 1 persen maka keputusan nasabah memilih CU Cinta Kasih Tigapanah $(\mathrm{Y})$ akan naik sebesar 0,354 satuan.

7. Nilai koefisien regresi variabel proses (X6) sebesar 0,440 artinya bila prosesmeningkat 1 persen maka keputusan nasabah memilih CU Cinta Kasih Tigapanah (Y) akan naik sebesar 0,440 satuan.

8. Nilai koefisien regresi variabel bukti fisik (X7) sebesar 0,237 artinya bila bukti fisikmeningkat 1 persen maka keputusan nasabah memilih CU Cinta Kasih Tigapanah (Y) akan naik sebesar 0,237 satuan.

Dilihat dari persamaan regresi linier berganda diatas dapat disimpulkan bahwa produk, harga, lokasi, promosi, orang, proses, dan bukti fisik berpengaruh positif terhadap keputusan nasabah memilih CU. Cinta Kasih Tigapanah dan proses mempunyai pengaruh yang lebih besar terhadap keputusan nasabah memilih CU Cinta Kasih Tigapanah dibandingkan dengan produk, harga, lokasi, promosi, orang dan bukti fisik.

Tabel 5: Koefisien Determinasi $\left(\mathbf{R}^{2}\right)$

\begin{tabular}{|l|r|r|r|r|}
\hline Model & \multicolumn{1}{|c|}{ R } & R Square & Adjusted R Square & Std. Error of the Estimate \\
\hline 1 & $.924^{\mathrm{a}}$ & .854 & .842 & 1.05874 \\
\hline \multicolumn{7}{|l}{ a. Predictors: (Constant), Bukti_Fisik, Lokasi, Promosi, Proses, Harga, Orang, Produk } \\
\hline
\end{tabular}

Sumber :Data diolah dengan SPSS

Tabel 5 menunjukkan Koefisien determinasi (R Square) adalah sebesar 0,854 atau $85,4 \%$ berarti variasi keputusan nasabah memilih CU. Cinta Kasih Tigapanah dapat dijelaskan oleh variasi produk, harga, lokasi, promosi, orang, proses, bukti fisik sebesar $85,4 \%$ dan sisanya sebesar $14.6 \%$ dapat dijelaskan oleh variabel lain yang tidak termasuk dalam penelitian ini antara lain seperti kualitas pelayanan, strategi pemasaran.

\section{Pengaruh Produk Terhadap Keputusan Nasabah Memilih CU. Cinta Kasih Tigapanah}

Berdasarkan out put SPSS pada Tabel 4.41 dapat dilihat bahwa secara parsial nilai signifikan untuk variabel produk adalah 1,895 sedangkan nilai $t_{\text {tabel }}$ adalah sebesar 1,98729 sehingga 1,895<1,98729. Selain itu untuk nilai signifikansinya $(0,061>0,05)$ dengan memperhatikan nilai $\mathrm{t}_{\text {tabel }}$ maka $\mathrm{H}_{0}$ diterima dan $\mathrm{H}_{1}$ ditolak. Dengan diterimanya $\mathrm{H}_{0}$ berarti produk tidak berpengaruh positif dan tidak signifikan terhadap keputusan nasabah memilih CU. Cinta Kasih Tigapanah. Dengan demikian indikator dari variabel produk yaitu kinerja, reliabilitas, kesesuaian dengan spesifikasi, dan kemampuan melayani perlu diperhatikan supaya dapat mempengaruhi keputusan nasabah memilih CU Cinta Kasih Tigapanah.

Produk yang sesuai dengan kebutuhan dan keinginan konsumen akan menarik perhatian konsumen untuk memiliki rasa ingin memiliki atas barang atau jasa yang dipasarkan, dan baiknya kualitas produk juga akan menjadi bahan pertimbangan konsumen dalam memilah produk apa yang akan dibeli.

Pengaruh Bauran Pemasaran Jasa Terhadap Keputusan Nasabah Dalam Memilih CU Cinta Kasih 43

Tigapanah.

Oleh : Refi Mariska, Darna Sitanggang 


\section{Pengaruh Harga Terhadap Keputusan Nasabah Memilih CU. Cinta Kasih Tigapanah}

Berdasarkan out put SPSS pada Tabel 4.41 dapat dilihat bahwa secara parsial nilai $t_{\text {hitung }}$ untuk variabel harga adalah 0,724 sedangkan nilai $t_{\text {tabel }}$ adalah sebesar 1,98729 sehingga $0,724<1,98729$. Selain itu untuk nilai signifikansinya $(0,471>0,05)$ dengan memperhatikan nilai tabel maka $\mathrm{H}_{0}$ diterima dan $\mathrm{H}_{1}$ ditolak. Dengan diterimanya $\mathrm{H}_{0}$ berarti harga tidak berpengaruh positif dan tidak signifikan terhadap keputusan nasabah memilih CU. Cinta Kasih Tigapanah.Dengan demikian indikator dari variabel harga yaitu kesesuaian harga dengan kualitas produk, kesesuaian harga dengan manfaat produk, harga sesuai dengan kemampuan atau daya saing harga perlu mendapat perhatian yang lebih seriussupaya dapat meningkatkan keputusan nasabah memilih CU. Cinta Kasih Tigapanah.

Harga yang ditetapkan harus sesuai dengan kualitas produk dan manfaat produk, serta kemampuan atau daya saing harga karena jika harga selalu naik maka nasabah akan semakin sedikit karena harga yang terlalu mahal, sehingga manajer harus cermat dalam menetapkan harga yang ditetapkan melalui diskon, cash back, dan lainnya.

\section{Pengaruh Lokasi Terhadap Keputusan Nasabah Memilih CU. Cinta Kasih Tigapanah}

Berdasarkan out put SPSS pada Tabel 4.41 dapat dilihat bahwa secara parsial nilai $t_{\text {hitung }}$ untuk variabel lokasi adalah 0,381 sedangkan nilai $t_{\text {tabel }}$ adalah sebesar 1,98729 sehingga $0,381<1,98729$. Selain itu untuk nilai signifikansinya $(0,704>0,05)$ dengan memperhatikan nilai $t_{\text {tabel }}$ maka $\mathrm{H}_{0}$ diterima dan $\mathrm{H}_{1}$ ditolak. Dengan diterimanya $\mathrm{H}_{0}$ berarti lokasi tidak berpengaruh positif dan tidak signifikan terhadap keputusan nasabah memilih CU. Cinta Kasih Tigapanah. Dengan demikian indikator dari variabel lokasi yaitu akses visibilitas, lalu lintas, tempat parkir yang luas, ekspansi, lingkungan, dan lokasi pesaing perlu mendapat perhatian yang lebih seriussupaya dapat meningkatkan keputusan nasabah memilih CU. Cinta Kasih Tigapanah.

Lokasi adalah tempat produsen menyalurkan produknya kepada konsumen ataupun merupakan komitmen sumber daya jangka panjang.Semakin baik letak lokasi maka semakin tertarik orang menjadi nasabah CU Cinta Kasih Tigapanah.Peningkatan strategi dapat dilakukan dengan memilih lokasi yang mudah dijangkau, dan menyediakan bangunan serta tempat parkir yang luas sehingga keputusan nasabah memilih CU. Cinta Kasih Tigapanah akan meningkat.

\section{Pengaruh Promosi Terhadap Keputusan Nasabah Memilih CU. Cinta Kasih Tigapanah}

Berdasarkan out put SPSS pada Tabel 4.41 dapat dilihat bahwa secara parsial nilai $t_{\text {hitung }}$ untuk variabel promosi adalah 0,380 sedangkan nilai $t_{\text {tabel }}$ adalah sebesar 1,98729 sehingga $0,380<1,98729$. Selain itu untuk nilai signifikansinya $(0,705>0,05)$ dengan memperhatikan nilai $t_{\text {tabel }}$ maka $\mathrm{H}_{0}$ diterima dan $\mathrm{H}_{1}$ ditolak. Dengan diterimanya $\mathrm{H}_{0}$ berarti promosi tidak berpengaruh positif dan tidak signifikan terhadap keputusan nasabah memilih CU. Cinta Kasih Tigapanah. Dengan demikian indikator dari variabel promosi yaitu frekuensi promosi, kualitas promosi, kuantitas promosi dan ketepatan atau kesesuian sasaran promosiperlu ditingkatkanlagi sehingga dapat meningkatkan keputusan nasabah memilih CU. Cinta Kasih Tigapanah.

Promosi adalah kegiatan memasarkan produk kepada masyarakat, semakin baik cara karyawan pemasaran dalam memasarkan produknya maka semakin banyak masyarakat mengenal dan tertarik pada produk yang dipasarkan.

\section{Pengaruh Orang Terhadap Keputusan Nasabah Memilih CU. Cinta Kasih Tigapanah}

Berdasarkan out put SPSS pada Tabel 4.41 dapat dilihat bahwa secara parsial nilai $t_{\text {hitung }}$ untuk variabel orang adalah 2,407 sedangkan nilai $t_{\text {tabel }}$ adalah sebesar 1,98729 sehingga

Pengaruh Bauran Pemasaran Jasa Terhadap Keputusan Nasabah Dalam Memilih CU Cinta Kasih 44 Tigapanah.

Oleh : Refi Mariska, Darna Sitanggang 
$2,407>1,98729$. Selain itu untuk nilai signifikansinya $(0,018<0,05)$ dengan memperhatikan nilai $\mathrm{t}_{\text {tabel }}$ maka $\mathrm{H}_{0}$ ditolak dan $\mathrm{H}_{1}$ diterima. Dengan diterimanya $\mathrm{H}_{1}$ berarti orang berpengaruh positif dan signifikan terhadap keputusan nasabah memilih CU. Cinta Kasih Tigapanah.Dengan demikian indikator dari variabel orang yaitu kompetensi, kesopanan, selektif, dan komunikatif perlu dipelihara dan ditingkatkan karena dapat meningkatkan keputusan nasabah memilih CU. Cinta Kasih Tigapanah.

Orang adalah semua pelaku yang memainkan peranan dalam penyajian jasa sehingga dapat mempengaruhi persepsi pembeli.Peningkatan keputusan nasabah memilih CU. Cinta Kasih Tigapanah terjadi karena manajer pemasaran memiliki kriteria yang diterapkan dalam memilih karyawan, diantaranya karyawan harus memiliki kemampuan yang kompeten dalam menghadapi keluhan nasabah, memiliki sopan santun dalam melayani seluruh karyawan serta menjaga nama baik perusahaan dengan menjalin hubungan baik dengan nasabah ataupun calon nasabah dengan demikian maka keputusan nasabah memilih CU. Cinta Kasih Tigapanah akan semakin meningkat.

\section{Pengaruh Proses Terhadap Keputusan Nasabah Memilih CU. Cinta Kasih Tigapanah}

Berdasarkan out put SPSS pada Tabel 4.41 dapat dilihat bahwa secara parsial nilai $t_{\text {hitung }}$ untuk variabel proses adalah 4,000 sedangkan nilai $t_{\text {tabel }}$ adalah sebesar 1,98729 sehingga $4,000>1,98729$. Selain itu untuk nilai signifikansinya $(0,000<0,05)$ dengan memperhatikan nilai $t_{\text {tabel }}$ maka $\mathrm{H}_{0}$ ditolak dan $\mathrm{H}_{1}$ diterima. Dengan diterimanya $\mathrm{H}_{1}$ berarti proses berpengaruh positif dan signifikan terhadap keputusan nasabah memilih CU. Cinta Kasih Tigapanah. Dengan demikian indikator dari variabel proses yaitu kecepatan, kemudahan, ketelitian, dan penyampaian terhadap keluhan perlu dipelihara dan ditingkatkan karena dapat meningkatkan keputusan nasabah memilih CU. Cinta Kasih Tigapanah.

Proses dalam jasa merupakan gabungan semua aktivitas, umumnya terdiri dari prosedur, jadwal pekerjaan, mekanisme, aktivitas dan hal-hal rutin, di mana jasa dihasilkan dan disampaikan kepada konsumen. Peningkatan keputusan nasabah memilih CU. Cinta Kasih Tigapanah terjadi karena manajer pemasaran menerapkan kecepatan dalam proses transaksi. Kecepatan, yaitu penyedia jasa memberikan segala proses yang cepat dalam menyampaikan jasa yang akan dikönsumsi oleh konsumen sehingga konsumen tidak berlarut-larut menunggu jasa yang akan diperolehnya, serta meningkatkan ketelitian dan kemudahan dalan bertransaksi, sehingga nasabah mudah dalam memproses transaksi yang diinginkannya, karena hal tersebut nasabah yang memilih CU. Cinta Kasih Tigapanah meningkat.

Pada CU. Cinta Kasih Tigapanah proses memiliki pengaruh paling besar terhadap keputusan nasabah memilih CU. Cinta Kasih tigapanah dibandingkan variabel lainnya.

\section{Pengaruh Bukti Fisik Terhadap Keputusan Nasabah Memilih CU. Cinta Kasih Tigapanah}

Berdasarkan out put SPSS pada Tabel 4.41 dapat dilihat bahwa secara parsial nilai $t_{\text {hitung }}$ untuk variabel bukti fisik adalah 1,650 sedangkan nilai $t_{\text {tabel }}$ adalah sebesar 1,98729 sehingga $1,650>1,98729$. Selain itu untuk nilai signifikansinya $(0,103>0,05)$ dengan memperhatikan nilai $\mathrm{t}_{\text {tabel }}$ maka $\mathrm{H}_{0}$ diterima dan $\mathrm{H}_{1}$ ditolak. Dengan diterimanya $\mathrm{H}_{0}$ berarti bukti fisik tidak berpengaruh positif dan tidak signifikan terhadap keputusan nasabah memilih CU. Cinta Kasih Tigapanah.Dengan demikian indikator dari variabel bukti fisik yaitu lingkungan, tata letak, dan fasilitas tambahan perlu ditingkatkan supaya dapat meningkatkan keputusan nasabah memilih CU. Cinta Kasih Tigapanah.

Bukti fisik merupakan suatu hal yang secara nyata turut mempengaruhi keputusan konsumen untuk membeli dan menggunakan produk jasa yang ditawarkan.Hasil penelitian ini yang menyatakan tidak berpengaruh positif dan tidak signifikan yang berarti, CU. Cinta

Pengaruh Bauran Pemasaran Jasa Terhadap Keputusan Nasabah Dalam Memilih CU Cinta Kasih 45 Tigapanah.

Oleh : Refi Mariska, Darna Sitanggang 
Kasih Tigapanah kurang memperhatikan lingkungan sekitar, tata letak yang kurang strategis, serta tidak menambah fasilitas yang meningkatkan keputusan nasabah, karena hal ini nasabah kurang yakin untuk memilih CU. Cinta Kasih Tigapanah sebagai tempat transaksi simpan pinjam karena dianggap sebagai usaha yang kurang berkembang, dan memilih usaha sejenis lainnya sebagai tempat transaksi simpan pinjam.

Pengaruh Bauran Pemasaran Jasa (Produk, Harga, Lokasi, Promosi, Orang, Proses, Dan Bukti Fisik) Terhadap Keputusan Nasabah Memilih CU. Cinta Kasih Tigapanah

Berdasarkan output SPSS pada tabel 4.40 dapat dilihat bahwa terdapat pengaruh yangsignifikan antara variabel bebas yaitu produk, harga, lokasi, promosi, orang, proses, bukti fisik terhadap variabel terikat yaitu keputusan nasabah memilih CU Cinta Kasih

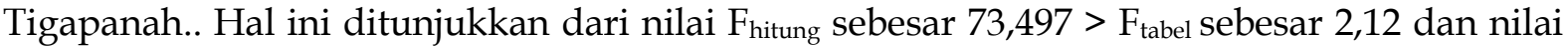
signifikan $\mathrm{F}$ sebesar $0,000<a(0,05)$ sehingga dapat disimpulkan bahwa secara simultan variabel produk, harga, lokasi, promosi, orang, proses, bukti fisik berpengaruh positif dan signifikan terhadap keputusan nasabah memilih CU. Cinta Kasih Tigapanah.

Indikator-indikator yang digunakan dalam kuesioner mampu menjelaskan variabel bauran pemasaran jasa (produk, harga, lokasi, promosi, orang, proses, dan bukti fisik) secara bersama-sama dengan baik hal ini terlihat dari total jawaban responden pada variabel bauran pemasaran (produk, harga, lokasi, promosi, orang, proses, dan bukti fisik) di interprestasikan bahwa yang paling banyak dipilih responden adalah jawaban sangat setuju dan setuju, hal ini sejalan dengan hasil SPSS variabel bauran pemasaran (produk, harga, lokasi, promosi, orang, proses,dan bukti fisik) yang valid dan reliable serta signifikan terhadap keputusan nasabah memilih CU. Cinta Kasih Tigapanah pada tingkat signifikannya $(0,000<0.05)$. Sehingga perusahaan perlu memperhatikan variabel bauran pemasaran (produk, harga, lokasi, promosi, orang, proses, dan bukti fisik) bersama-sama untukmeningkatkan keputusan nasabah memilih CU. Cinta Kasih Tiga Panah.

\section{KESIMPULAN DAN SARAN}

Berdasarkan hasil penelitian yang telah dilakukan, setelah melakukan analisis data mengenai pengaruh strategi pemasaranjasa terhadap keputusan nasabah dalam memilih CU Cinta Kasih Tigapanah.

1. Produk, harga, lokasi, promosi, orang, proses, dan bukti fisik secara simultan berpengaruh positif dan signifikan terhadap keputusan nasabah memilih CU. Cinta Kasih Tigapanah.

2. Produk, harga, lokasi, promosidan bukti fisik berpengaruh positif tetapi tidak signifikan terhadap keputusan nasabah memilih CU Cinta Kasih Tigapanah, sdangkan proses dan orang berpengaruh positif dan signifikan.

3. Nilai koefisien determinan (R Square) adalah sebesar 0,854 artinya, keputusan nasabah memilih CU. Cinta Kasih Tigapanah dapat dijelaskan oleh variasi produk, harga, lokasi, promosi, orang, proses, bukti fisik sebesar $85,4 \%$ dan sisanya sebesar $14.6 \%$ dapat dijelaskan oleh variabel lain yang tidak termasuk dalam penelitian ini.

Berdasarkan kesimpulan di atas, saran yang diberikan sebagai berikut:

1. Sebaiknya CU. Cinta Kasih Tigapanah memperhatikan variabel produk, harga, lokasi, promosi dan bukti fisik supaya dapat meningkatkan keinginan nasabah memilih CU. Cinta Kasih Tigapanah.

2. Sebaiknya CU. Cinta Kasih Tigapanah mempertahankan variabel orang dan proses sehingga dapat meningkatkan keputusan nasabah memilih CU. Cinta Kasih Tigapanah.

Pengaruh Bauran Pemasaran Jasa Terhadap Keputusan Nasabah Dalam Memilih CU Cinta Kasih 46

Tigapanah.

Oleh : Refi Mariska, Darna Sitanggang 


\section{DAFTAR PUSTAKA}

Alma Buchari, 2013. Manajemen Pemasaran Perusahaan Jasa.Bandung: Alfabetha Assauri Sofyan, 2007. Manajemen Pemasaran: Dasar, Konsep dan Strategi.Jakarta:Raja Grafindo Persada.

Hurriyati Ratih, 2005. Bauran Pemasaran dan Loyalitas Konsumen, Alfabeta, Bandung Kasmir, 2007.Bauran Pemasaran Bank, Edisi Revisi. Jakarta: Kencana

Kotler dan Keller, 2007.Manajemen Pemasaran, Jilid I. Edisi ke 13 Jakarta: Erlangga --Philip dan Gary Amstrong, 2012. Dasar - Dasar Pemasaran, Edisi Indonesia. Alih Bahasa Alexander Sindoro, Jilid 1. Jakarta: Perinhallindo

Lupioadi Rambat, Hamdani A. 2011. Manajemen Pemasaran Jasa,Edisi 2, Jakarta: Salemba Empat

Mursid, 2008.Manajemen Pemasaran, Jakarta: Bumi Aksara

Sugiono, 2008.Metode Penelitian Kuantitatif, Kualitatif dan $R$ \& D, Alfabetha Bandung

Tjiptono, Fandy. 2016. Pemasaran Jasa, Malang, Jawa Timur - Indonesia: Penerbit Baymedia Publishing

Penelitian:

Kurniawati.2017. Pengaruh Bauran Pemasaran Jasa Terhadap Keputusan Menginap Konsumen Pada Hotel Syariah Arini Surakarta.

Marlius Doni. 2016. Pengaruh Bauran Pemasaran Jasa Terhadap Minat Nasabah Dalam Menabung Pada Bank Nagari Cabang Muaralabuh 